\title{
PETRUS HISPANUS PORTUGALENSIS? ELEMENTOS PARA UMA DIFERENCIAC̣ÃO DE AUTORES
}

\author{
José Francisco Meirinhos \\ Faculdade de Letras da Universidade do Porto
}

\section{RESUMEN}

En la Historia de la filosofía figura Pedro Hispano Portugalense como filósofo, médico, científico, político y papa. Pero, ¿se trata de una o de varias personas? El autor de este artículo estudia algunos aspectos relacionados con la vida, la obra y la personalidad de Pedro Hispano, para distinguirlo de las personas con las que ha sido confundido. El autor distingue entre: 1) Pedro Hispano, O. P.; 2) Pedro Hispano Portugalense; 3) Pedro Hispano, médico, al que algunos confunden con Pedro Juliano, que fue papa, con el nombre de Juan XXI.

\begin{abstract}
The personality of Petrus Hispanus Portugalensis (13th century) is quite polifacetic: philosopher, physician, scientist, politician and pope. This gave reason for confounding Petrus Hispanus with other people. The author of this article studies some aspects related with the life, writings and personality of Petrus Hispanus in order to distinguish him from the people he has been confounded with. The author concludes that there are three differents persons: 1) Petrus Hispanus, O. P.; 2) Petrus Hispanus Portugalensis; 3) Petrus Hispanus, physician, whom some historians confounded with Petrus Julianus, who became a pope with the name of John XXI.
\end{abstract}

Segundo a tradição e a historiografia Pedro Hispano Portugalense distinguiu-se na filosofia e na ciência médica, mas também na vida académica, política e eclesiástica. Embora este percurso de vida faça dele um dos vultos mais destacados do século XIII, o conhecimento da sua biografia está obscurecida por estranhas lacunas e também são inúmeras as perplexidades suscitadas pela comparação das obras que lhe são atribuídas. Conservam-se hoje cerca de 450 manuscritos com pelo menos 37 obras diferentes atribuídas a Petrus Hispanus, para além de se conhecerem referências a outras seis obras hoje perdidas. Também é muito lacunar o conhecimento desse corpus de grande diversidade temática, que abrange uma boa parte do campo científico medieval: lógica e filosofia, teologia e mística, zoologia e biologia, medicina e alquimia, para além de textos perdidos sobre a matemática, a física, a embriogénese e a cosmologia. Pelos dados biográficos documentados e conhecidos deveria concluir-se que esta extensa 
obra teria sido quase toda escrita entre $1230 / 5$ e 1250 . Contudo, se olharmos para o conteúdo e para as orientações filosóficas de cada uma dessas obras, surgem imediatamente dúvidas sobre se todas teriam sido escritas por um só, ou por vários Pedros Hispanos.

Em testemunhos de alguns contemporâneos de João XXI podemos ler apreciações muito negativas da sua personalidade, mas os historiadores eclesiásticos sempre procuraram engrandecer a estatura intelectual deste papa, baseando-se em todas as referências a Petrus Hispanus, com quem é identificado, por mais vagas e lendárias que fossem, sem submeter estas fontes a uma crítica de validade. Tendo como ponto de partida essas reconstituições biográficas também a historiografia filosófica mais recente, com algumas excepções apressadamente rebatidas, praticou uma leitura concordista entre as obras que lhe são atribuídas, realçando semelhanças por vezes apenas superficiais, com o objectivo de conciliar em um único autor aquela multiplicidade de obras e orientações.

Apesar deste esforço "concordista" uma análise mais detalhada do "puzzle" Pedro Hispano mostra como esta leitura tem sido construída sobre uma sucessão de hipóteses, que passaram a ser tomadas como certeza pelo autor ou autores seguintes. Talvez por isso, o dossier Pedro Hispano é excessivamente complexo e lacunar, o que justifica uma outra abordagem do problema, que assente num princípio da não identidade de altores entre os vários grupos de obras que the são atribuídas e que averigúe as diferenças entre os vários personagens que parecem emergir da documentação até agora tida como testemunho de identidade entre Pedro Hispano e João XXI. ${ }^{1}$ Seguindo estas orientações neste breve contributo abordar-se-á de uma forma sintética e problematizadora a vida, obra e pensamento de Pedro(s) Hispano(s). Assim, no $\S 1$ são analisados os elementos biográficos documentados, que em verdade contrariam ou são menos peremptórios que muitas das interpretações e hipóteses tradicionais que deles têm sido feitas e que admitem a hipótese de estarmos perante vários e não um Pedro Hispano único. No $\S 2$ caracterizam-se as obras, sua influência, e orientações filosóficas, elementos que atestam como também é problemática a tese do autor único. De acordo com esses indícios e com o intuito de simplificar e resolver a "questão Pedro Hispano", propõe-se numa breve conclusão a distinção entre três personagens: Petrus Hispanus O.P., Petrus Hispanus portugalensis, Petrus Hispanus medicus. Apenas este último poderia ser identificado com o Petrus Juliani que veio a ser papa com o nome de Johannes XXI.

\section{O PROBEEMA BIOGRÁFICO}

A 20 de Maio de 1277 morria em Viterbo o papa João XXI, cujo nome secular era Petrus Juliani, vitimado pela queda acidental do tecto dos aposentos que, segundo a tradição, manda-

1 Tive oportunidade de apresentar alguns aspectos da hipótese da multiplicidade de autores em 1992 no Seminario de Filosofia Medievale de Alfonso Maierù, de quem recebi profícuas orientaçōes metodológicas que me incentivaram a prosseguir a investigação deste problema histórico-filosófico. Também tive oportunidade de expor esta hipótese na cátedra de Filosofia Medieval de Mário A.S. de Carvalho na Universidade de Coimbra em 1994. 
ra edificar no palácio papal para aí se poder dedicar com calma aos assuntos científicos que desde sempre o haviam interessado. Esta morte súbita provocou uma forte impressão no imaginário medieval, que a interpretou de múltiplas maneiras, uns viram-na como um castigo para a conduta reprovável do papa, outros lamentaram o prejuízo que adveio para a cristandade com a interrupção de um papado promissor. ${ }^{2}$ Estes primeiros cronistas coincidem em considerar João XXI um homem de ciência, que nasceu em Lisboa e que o seu nome secular era Petrus Juliani. Se não restam dúvidas quanto a estes factos, muitos outros marcos biográficos estão por determinar: data de nascimento, origens familiares, formação académica, universidades e faculdades onde estudou ou ensinou, identificação dos protectores pontifícios, percurso eclesiástico e na cúria papal, etc. Por outro lado, nenhum documento coetâneo estabelece ou permite estabelecer de modo inquestionável a ligação entre o Pedro Hispano lógico, o Pedro Hispano médico em Siena, o mestre Pedro Julião porta-voz do rei Afonso III de Portugal e deão da Sé de Lisboa. Apenas parece incontestável que o deão e mestre das escolas de Lisboa, bispo eleito de Braga e cardeal de Túsculo foi o papa João XXI. A associação do papa com o lógico e filósofo ou com o médico de Siena é plausível mas indocumentada, para além de duvidosa se tivermos em conta o conteúdo das obras a conciliar. O melhor argumento para a tese do "personagem único" é a não existência de contradições cronológicas flagrantes entre os factos conhecidos, mas também não podemos esquecer que dos séculos XII e XIII se conhecem ainda mal outros sete ou oito personagens diferentes, quer espanhóis quer portugueses, com o nome Petrus Hispanus e aos quais poderiam caber algumas das obras ou factos documentados. ${ }^{3}$

Uma vez que também faltam outras informações seguras, conhecer a data de nascimento de Pedro tem sido considerado um ponto de partida sólido para a reconstituição da sua vida e para estabelecer uma cronologia das obras. Como não existem elementos seguros que permitam fixá-la, tem-se recorrido à formulação de hipóteses, nem sempre assentes em factos comprovados. Nos estudos que antecederam a edição crítica do Tractatus ou Summulae logicales, a mais famosa e difundida das obras atribuídas a um Pedro Hispano, Lambert M. de Rijk carreou abundantes elementos novos, o mais importante dos quais era a datação de um comentário a essa obra realizado em Toulouse por mestre Guillelmus Arnaldi entre 1235-1244, daí se deduzindo que o Tractatus tinha sido escrito alguns anos antes. ${ }^{+}$Assim, De Rijk situou a com-

2 Sobre estes múltiplos testemunhos, ver Rossi, Paolo: «Pietro Ispano nel giudizio dei cronisti contemporanei», in Estudos Italianos em Portugal. 14-15 (1955-56) 4-17, ou FERREIRA: João: «Importância histórico-filosófica de Pedro Hispano no contexto da Escolástica», in Leopoldianum, 11 (1984) 99-110 (cfr. 99-100 e notas). O papado de João XXI foi geralmente visto de forma pouco favorável, para um exemplo recente ver: FLICHE: A.: «Un pape portugais: Jean XXI (1276-1277)», in Congresso do mundo português, vol. II (pp. 663-674) Lisboa 1940.

3 Sobre os homónimos de Pedro Hispano; ver as pp. 6-7 do artigo de Rossi (cit. nota anterior) e o estudo de Pontes, J. M. da Cruz: «A propos d'un centenaire: Une nouvelle monographie sur Petrus Hispanus Portugalensis, le pape Jean XXI (†1277) est-elle nécessaire?», in Recherches de Théologie Ancienne et Médiérale, 44 (1977) 220230.

4 Ruk, Lambert M. de: PETER OF SPAN, Tractatus, Called Afterwards Summulae logicales. First Critical Edition from the Manuscripts, Van Gorcum. Assen 1972, p. xcv, onde se remete para Riık, Lambert M. de: «On the Genuine Text of Peter's Summule logicales. IV: The Lectura Tractatumm by Guillelmus Arnaldi, Master of Arts at Toulouse (1235-44). With a Note on the Date of Lambert of Auxerre's Summule», in Vivarium 7 (1969) 120-162. 
posição da obra na década de 1230 e logicamente retrodatou o nascimento de Pedro Hispano para cerca de $1205,{ }^{5}$ revendo assim todas as cronologias que habitualmente situavam o nascimento de Pedro por volta de 1220. Esta "antecipação" do nascimento de Petrus Hispanus era fundamental para poder integrá-lo no curso de vida testemunhado por inúmeros documentos descobertos em Siena e em Portugal, os quais atestam factos posteriores a 1245 e no contexto dos quais não cabe a redacção do Tractatus, que, portanto, deveria ter ocorrido antes. Mas, recentemente R.-A. Gauthier mostrou no prefácio à edição do comentário de Tomás de Aquino sobre o Peri hermeneias que o comentário de Arnaldi ao Tractatus contém uma citação literal de Tomás de Aquino (citado como «expositor») e de Egídio de Roma e que, portanto, foi escrito no final do séc. XIII. ${ }^{6}$ Também os comentários de Roberto Ânglico, que de Rijk localizava cerca de 1240 , não devem ser anteriores a $1270 .{ }^{7}$ Com esta descoberta, ficou infirmada a hipótese fundamental de de Rijk, e ficou-se de novo sem um elemento que permitisse apontar para uma data de nascimento de Pedro Hispano e para o início da sua carreira académica. ${ }^{8}$ Por isso, embora se saiba que o Petrus Juliani, que foi papa sob o nome de João XXI, morreu em 1277 , dos dados conhecidos apenas se poderá propor que terá nascido entre 1200 e 1220 .

Os elementos disponíveis para uma reconstituição biográfica, são as poucas referências internas das obras ou os documentos onde se regista o nome de Pedro Hispano, os quais provêm dos cartórios ou chancelarias das instituições de poder a que ele (ou os seus homónimos) esteve ligado: a universidade, o poder régio português, a cúria papal. ${ }^{9}$

Lê-se no final da Scientia libri de anima: «Eu, Pedro Hispano Portugalense, doutor em artes liberais, regente da sublimidade filosófica, honra da faculdade de medicina e profícuo reitor, decidi compor esta obra principal sobre a ciência da alma». ${ }^{10}$ Esta auto-descrição é muito interessante porque evoca uma preenchida carreira universitária e porque identifica com precisão os domínios científicos em que decorreu: artes liberais, filosofia e medicina. Por estas

estudo onde são editadas extensas passagens do comentário de Arnaldi. Ver também os anteriores estudos desta série, publicados por de Rijk na mesma revista.

5 IDEM, Tractatus, p. xxx.

6 Gauther, René-Antoine: «Préface», in: Sancti Thomae de Aquino, Expositio libri peryermenias, Opera Omnia, t. I*1. Comissio Leonina-Libr. Philos. J.Vrin. Roma—Paris 1989. pp. 52*-53*. Apesar desta descoberta, Gauthier não põe em causa a atribuição do Tractatus a Petrus Hispanus-Iohannes XXI.

7 IDEM, ibidem: p. 52* e 56*.

8 Apesar do estudo de Gauthier, de Rijk repetiu de modo lacónico as suas datações anteriores na introdução à edição da outra obra lógica de Pedro Hispano, cfr.: PETER OF SPAIN (Petrus Hispanus Portugalensis) Sincategoreumata. First Critical Edition with an Introduction and Indexes by L.M. DE RIJK, with an English translation by Joke SPRUYT, E.J. Brill, Leiden 1992, p. 9.

9 Um estudo de alguns destes documentos relacionados com as actividades político-eclesiásticas de Pedro Hispano encontra-se em ANTUNES, José: «O percurso e o pensamento político de Pedro Hispano. Arcebispo eleito de Braga e Papa João XXI»s, in: IX Centenário da dedicação da Sé de Braga. Vol. II/1 (pp. 125-184). Cabido da Sé de Braga, Braga 1990.

10 «Ego igitur Petrus hispanus Portugalensis, liberalium artium doctor, phylosophice sublimitatis gubernator, medicinalis facultatis decor, ac proficue rector, in scientia de anima decrevi hoc opus precipuum componendum», Scientia... XIII 8, p. 498, edição de Alonso Alonso, M.: Pedro Hispano. Obras Filosóficas I. Scientia libri de anima (Libros Pensamiento 4) Juan Flors Ed., Barcelona 1961, 2a ed. 
razões tem sido tomada como argumento da unidade das obras e percurso atribuídos a Pedro Hispano. Infelizmente nada nos é dito quanto aos lugares onde essa carreira se desenrolou e com facilidade se associa este trecho ao papa João XXI, que estudou em Paris, porque o próprio o diz na bula Flumen aque vive de 28 de Abril de 1277 (portanto posterior à famosa condenação de 219 teses pelo bispo Tempier) dirigida ao bispo de Paris solicitando-lhe que indagasse certos erros que se ensinavam na Universidade da cidade: «tendo vivido nos seus lares [de Paris] durante muito tempo, desde os tenros anos, aí nos dedicámos com diligência ao estudo das várias ciências e permanecendo por muitos anos junto do curso do rio provámos as libações saborosíssimas dessas mesmas ciências». " Que Pedro Hispano esteve ligado ao meio universitário é indubitável, pois as obras que lhe estão atribuídas têm origem em lições proferidas ou estão ligadas aos modelos da tratadística ou do ensino universitário medieval, mas afinal esta condição é comum à generalidade das obras do século XIII sobre os mesmos temas. Por outro lado, estas mesmas palavras da bula poderiam ter sido ditadas por ou sobre quem nunca escreveu qualquer obra.

A escassez de informações biográficas seguras não permite esclarecer várias questões importantes: em que anos decorreram os estudos referido? quem foram os seus mestres? foi mestre de artes em Paris? foi aí que estudou medicina? em que universidades ensinou? etc. Se exceptuarmos os comentários médicos (que terão sido compostos em Siena entre 1245 e 1250), desconhece-se em absoluto onde, em que condições e em que contexto escolar as outras obras foram produzidas.

Sobre Petrus Yspanus conhecem-se cinco documentos anteriores a 1250, todos de Siena, Itália. O primeiro é um curioso e mundano documento notarial, datado de 11 de Janeiro de 1245, no qual «mestre Pedro médico, chamado Hispano (magister Petrus medicus, qui dicitur Yspanus)» se compromete a pagar uma indemnização de 50 libras de Siena a Maria de Ruberto se faltar à promessa de não a ofender. Ao certo não sabemos o que fazia Pedro Hispano em Siena, mas como uma das testemunhas do acto é Ranieri Caccianievi, reitor do Hospital da Scala, não é de descartar que Pedro aí exercesse alguma função médica. É apenas uma hipótese que já fosse professor no studium comunal fundado no ano anterior. Por um outro documento, de 1248, o mesmo Pedro vende uma magnífica Bíblia ornamentada e bem encaderna$\mathrm{da}$, o que parece indicar que estaria em dificuldades económicas. Um documento comunal de 1248 testemunha pagamentos que lhe foram feitos como professor do studium, mas não sabemos se Pedro Hispano se encontrava em Siena como prático de medicina e terá então sido con-

11 «In illius namque laribus ab annis teneris diucius obversati variis scienciis inibi studiose vacabimus et per annos plurimus secus decursus sedentes ipsarum sapidissima earum libamenta gustavimus», ed. e trad. em SÁ. A. Moreira de: «Pedro Hispano e a crise de 127.7 da universidade de Paris», in Boletim da Biblioteca da Universidade de Coimbra. 22 (1955) 223-241, cf. p. 238. Neste estudo inclui-se a edição e tradução das bulas de João XXI relacionadas com a condenação de 7 de Março de 1277. Quanto a mim esta bula de 28 de Abril de 1277 é uma reelaboração literária (e portanto nunca expedida) pelo notário papal Berardo de Nápoles, da bula enviada em 8 de Janeiro de 1277 ao bispo Tempier, a única relacionada com a condenação de 7 de Março de 1277. A ser assim, poderíamos perguntar-nos se a referência tem algum valor auto-biográfico, ou se constitui um mero ornato literário, ou se exprime algo que Berardo sabia sobre a vida do papa. 
tratado como professor, ou se se deslocou para a cidade atraído pela nova Universidade, fundada por volta de 1240 , onde se ensinava gramática, dialéctica, direito civil e medicina. Em Abril de 1250 é remunerado pela Comuna de Siena por ter realizado uma consulta médica, e em Junho do mesmo ano recebe honorários pelo magistério no Studium. ${ }^{2}$ Esta Universidade de Siena é, assim, a única a que comprovadamente sabemos que esteve ligado como professor um Pedro Hispano, e tudo indica que este aí tenha escrito pelo menos a maioria dos comentários de medicina que lhe são atribuídos.

Nas biografias de Pedro Hispano também é habitual uma referência a ligações científicas com a corte do Imperador Frederico II, fundamentadas numa dedicatória de autenticidade contestada, ${ }^{13}$ mas, para além de referências muito indirectas no De oculo, nenhum escrito ou documento indicia esta ligação. $O$ certo é que este Petrus Yspanus médico ensina em Siena no período em que a cidade está sob a soberania do imperador Frederico II e, curiosamente, o último registo da sua presença em Siena é de Junho de 1250, exactamente o ano da morte do Imperador. ${ }^{1+}$

A partir desta data surge abundante documentação portuguesa sobre um Magister Petrus, umas vezes chamado Juliani e outras designado pelo seu cargo de Deão da Sé de Lisboa, ou por outros inúmeros cargos que acumulou. Convém assinalar que neles, nunca é referido como «medicus» ou como «Hispanus», nem nunca é assinalada uma qualquer ligação com Itália ou com universidades francesas. Trata-se de documentos associados a actividades eclesiásticas e relacionadas com o poder político e eclesiástico em Portugal. ${ }^{15}$

Em um documento de 11 de Junho de 1250 (portanto do mesmo mês do último documento de Siena!) emanado das Cortes nacionais reunidas em Guimarães, é referido «Mestre Pedro

12 Cfr. NARDI; Paolo: «Comune, Imperio e papato alle origine dell 'insegnamento universitario in Siena (1240-1275)»: in Bulletino Senese di Storia Patria, 90 (1984) 50-94, sbd. pp. 65 e 70.

13 No prefácio ao De regimen sanitatis, que se conserva no manuscrito London. B.M., Harleian $5218(\mathrm{H})$ lêse: «Epistula Magistri Petri Hispani missa ad Imperatorem Fridericum super regimen sanitatis./ Suo domino pre cunctis mortalibus metuendo Frederico Romanorum Imperatori fontis Pegasei liquore instructo Magister Petrus Hispanus eius alumpnus senex [corr.: senensis] artis medicine professor seipsum et opus conseruande recipere sanitatis.» Em nenhum dos outros manuscritos que contêm a obra se lê este início do prefácio, cf. Obras Médicas de Pedro Hispano. Pref., introd., trad. e notas de M.H.R. PereiRA (Acta Universitatis Conimbrigensis) Coimbra 1973, p. 447 e cf. pp. 436-437. Charles H. Haskins, que várias vezes repetiu a ligação de Pedro Hispano com Frederico II. também duvidou da autenticidade deste prefácio, no artigo «Latin Literature under Frederick II», círculo cultural onde inclui um «Petrus Hispanus (later Pope John XXI), if we accept the doubtful ascription in Harleian Ms 5218, f. 1: Epistola magistry Petri Hyspani missa ad imperatorem Fridericum super regimen sanitatis» (Haskins, Ch. H.: Studies in Mediaeral Culture, Frederick Ungar Publishing Co., New York 1929. p. 131).

14 Cfr. NARDI, P.: «Comune, Imperio e papato...», art. cit. pp. 69-76. Este estudioso é muito cauteloso na identificação do Petrus Yspanus médico em Siena com o papa João XXI, porque os documentos de Siena nunca 0 mencionam como Petrus Juliani e porque nehuma outra fonte posterior refere a sua passagem por Siena. Ao mesmo tempo e com todo o realismo: considera que é ainda mais árduo defender que se trata de personagem distinto e reconstruir a sua biografia com base na documentação conhecida (cf. p. 73).

15 Podem encontrar-se estes documentos em: SÁ, Artur Moreira de, «Primórdios da cultura portuguesa», in Arquiros de História da cultura portuguesa. V/1 (1966) sbd. pp. 59-94; doc. 39-59; e em CAEIRO, Francisco da Gama: «Novos elementos sobre Pedro Hispano. Contribuição para o estudo da sua biografia», in Revista Portuguesa de Filosofia» 22 (1966) 157-173. 
Julião, deão de Lisboa e arquidiácono de Braga». ${ }^{16}$ Este documento, onde é citado com vários títulos, atesta a proximidade de Pedro com o rei Afonso III, que nessas Cortes o apresenta como porta-voz para dialogar com os representantes do clero com quem estava em conflito. É no mínimo estranho que pouco tempo antes, em Siena, sobrevivesse com manifestas dificuldades e de repente apareça em Portugal com sólidos privilégios e rendas e protecção real. Nos anos posteriores a 1250 será mencionado em diversos documentos (por exemplo nos actos relacionados com as Cortes nacionais de Leiria em 1254) onde surge sempre ao lado do rei Afonso III, que em 1257 o apresenta para prior de Santa Maria de Guimarães, o mais rico e rentável priorado português de então. Como o detentor da renda não a cedia, Pedro envolveuse numa longa disputa pelo usufruto desses rendimentos, que apenas seria resolvida na cúria em 1273. Num documento relacionado com este caso insere-se uma apreciação muito laudatória e em retórica curialística sobre Pedro Julião, escrita pelos cardeais de S. Maria in Cosmedin e de S. Cosme e Damião, árbitros na contenda sobre o usufruto dos benefícios da Igreja de Santa Maria de Guimarães. Nesse parecer, citado numa Bula de Urbano IV de 28 de Outubro de 1263, dizem os cardeais: «O suave odor da vossa fama, que se desprende do dom de eminente ciência, dos méritos da vida, da múltipla probidade e do estudo das vossas louváveis acções, enche com sua fragrância a casa de Deus (...)» e acrescentam que conhecendo «a vossa eminente ciência das letras, a gravidade dos costumes, a pureza de vida e outros méritos», dão provimento à súplica de Pedro Julião, aceitando ainda que mantenha «na Igreja de Lisboa, o magistério das escolas e o deado, bem como os benefícios que mantendes noutras igrejas». ${ }^{17}$ Neste documento, dirigido a «Magister Petrus Juliani ... archidiacono Bracharensi» e que o papa considera «venerabilis», vemos emergir uma personalidade ciosa de privilégios e que luta e apela tenazmente pela sua conservação, sobre a qual não são referidas actividades académicas nem a fama de obras escritas.

Entretanto, a relação com o rei Afonso III parece ter sofrido um forte revés quando, por volta de 1259-60, Pedro Julião disputou e perdeu a eleição para bispo de Lisboa, com a escolha do cabido a recair sobre o mestre-escola Mateus, um leal partidário do rei. Também neste caso Pedro recorre para o papa, solicitando a anulação da eleição por pretensas intromissões abusivas do poder secular no processo. Terá sido este o motivo que o leva em 1261-62 à cúria pontifícia, em Anagni, onde o diferendo viria a ser resolvido por volta de $1263 \mathrm{com}$ a confirmação de mestre Mateus como bispo de Lisboa, sendo Pedro nomeado seu sucessor como Mestre-escola de Lisboa. ${ }^{18}$ Desconhece-se se dirigiu mesmo a escola catedralícia de Lisboa e quais as medidas que possa ter tomado com vista à constituição ou promoção de estudos, até porque desde 0 início dos anos 60 nos surge em Itália, cada vez mais embrenhado em actividades da cúria pontifícia.. Em 1272 viria a ser eleito arcebispo de Braga, por decisão unânime

16. In SÁ. A.M., «Primórdios...», art. cit., pp. 59-60.

17 Esta bula (com tradução de M. Pinto de Meneses) encontra-se em SÁ. A. Moreira de: «Pedro Hispano, prior da Igreja de Santa Maria de Guimarães e arcebispo da Sé de Braga», in Biblos 30 (1954) 1-24 (cf. pp. 10-15).

18 A este cargo se referem já os Cardeais no excerto referido na nota anterior. Sobre estes factos ver: Antunes. J., "O percurso e o pensamento político de Pedro Hispano...», art. cit., pp. 136 e segg. 
do cabido, mas não foi consagrado, certamente porque estava fora do país e porque pouco depois foi elevado a cardeal de Túsculo em Itália. O período 1250-1273, no qual o seu percurso está bem documentado, foi de grande actividade política, mas não se lhe conhecem actividades científicas ou académicas. Deve ser realçado que nestes documentos Petrus Juliani nunca é citado como médico e nunca são feitas referências nem a obras que tenha escrito, nem a anteriores ligações com universidades.

Contrariamente ao que sempre se disse, mais do que o prestígio científico, que nunca é atestado pelos documentos, devem ter sido os litígios pela eleição para bispo de Lisboa e pelos benefícios do priorado de Santa Maria de Guimarães que levaram Pedro Julião à cúria pontifícia a partir de 1261. As primeiras referências aparecem nos registos papais de Alexandre V, são de 1260 e estão relacionadas com a disputa do bispado de Lisboa, mas não é certo que Pedro já estivesse na cúria. ${ }^{19} \mathrm{~A}$ sua intervenção como testemunha de decisões papais ou cardinalícias é atestada por grande quantidade de documentos a partir de 31 de Dezembro de 1261, nos quais surge quase sempre directamente associado à família curial do cardeal Ottobono Fieschi, que podemos considerar seu protector, que subiu ao sólio pontifício como Adriano V em 1276, e ao qual o próprio Pedro Julião haveria de suceder.

Em estudo recente Paravicini Bagliani chamou a atenção para o infundado de duas afirmações constantemente repetidas. Contrariamente ao que sempre se aceitou e repetiu, não existe qualquer documento que ateste que Pedro foi médico na cúria pontifícia, nem de Urbano IV, nem mesmo de Gregório X. Segundo outra antiga opinião, teria escrito o receituário Thesaurus pauperum na cúria quando arquiatro de Gregório X, mas esta hipótese também carece de fundamento, até porque nenhum documento 0 refere nesta função. ${ }^{20}$ Conviria começar por averiguar quando começou a ser afirmado que Petrus Juliani era médico. Mas, também aqui uma hipótese plausível é que se trate de uma associação de nomes algo tardia, fundada em vagas memórias e tradições orais difusas que permitiram que o comum etnónimo "Hispanus" fizesse assimilar em um indivíduo a biografia de dois ou mais personagens completamente diferentes.

De qualquer forma, mesmo que o seu papel como médico da cúria tenha sido reduzido ou nulo, a carreira eclesiástica de Petrus Juliani será fulgurante e bem sucedida. Gregório X elevao em 3 de Junho de 1273 a bispo cardeal de Túsculo, Itália. Nesta condição assiste em 1274 ao II concílio de Lyon. Em 1276, na sequência de uma série de quatro curtíssimos pontificados, Pedro Julião seria eleito papa por um colégio de sete ou oito cardeais reunido em Viterbo, escolhendo para seu nome João XXI (um pequeno erro de contagem, pois nunca houve um papa João XX).

19 Cf. Paravicin Bagliani, A.: «Medici e ricette mediche alla corte papale del duecento», in Idem: Medicina e scienze della natura alla corte dei papi nel duecento (Biblioteca di "Medioevo latino" 4) CISAM. Spoleto 1991. p. 28.

20 Para tudo isto cfr. Paravicini Bagliani, A.: Medicina e scienze della natura .... pp. 28, 32, 78, etc. Em outros estudos publicados pelo mesmo autor em datas anteriores e reunidos neste volume, é ainda aceite a tradição que toma Pedro como arquiatro de Gregório X. cf. pp. 106, 243, etc. É pressuposto em todas as referências que João XXII é o famoso médico Pedro Hispano, também autor de obras lógicas e filosóficas. 
Durante o seu pontificado João XXI não descurou nenhum dos instrumentos de exercício do poder político: deliberações, diplomacia, governo, preparação da "guerra justa". ${ }^{21}$ Fiel ao espírito do concílio de Lyon II e ao projecto ecuménico de Gregório X, prosseguiu os esforços de unificação da cristandade empenhando-se em três frentes: pacificação dos litígios entre casas reais, realização de uma cruzada para reconquista de Jerusalém, negociações de unificação com a Igreja cristã do Oriente. ${ }^{22}$ Iniciativas interrompidas ou adiadas devido à sua morte inesperada.

O nome de João XXI ficaria ainda negativamente ligado a um dos grandes pontos de viragem da filosofia no século XIII. De facto, a condenação de 219 proposições pelo bispo de Paris em 17 de Março de 1277, teve origem numa curta bula, onde o papa solicitava um relatório detalhado sobre erros e doutrinas contra a fé ensinados em Paris. ${ }^{2.3}$ Contrariamente a uma hipótese de Grabmann que Callebaut realçou, ${ }^{2+}$ a seu tempo acolhida por Gilson ${ }^{25}$ e tantas vezes repetida, ${ }^{26}$ João XXI não terá pretendido censurar e silenciar teorias do conhecimento adversárias das suas, mas apenas obter informações. Aliás, aquela interpretação do papel do papa só surgiu depois de se conhecerem os textos psicológicos descobertos por Grabmann. Pelo texto da bula «Relatio nimis implacida...» de 18 de Janeiro de 1277 depreende-se que ao próprio papa teria sido feito um relato prévio, que o induziu a solicitar a realização daquela inquirição episcopal na Universidade de Paris. Tudo indica que o acto de condenação foi da exclusiva iniciativa do bispo Tempier e da sua comissão, que ultrapassou o mandato do papa, que não lhe dera esses poderes.

Como já se referiu acima, segundo a tradição, João XXI mandou construir uma nova ala do palácio papal de Viterbo para aí se dedicar com calma ao estudo, mas, por acidente ou atentado, o tecto desses aposentos ruiu quando lá se encontrava e atingiu-o, vindo a morrer seis ou sete dias depois, em consequência dos ferimentos sofridos. Este e outros factos viriam a amalgamar-se nas narrativas da morte de João XXI, que oferecem todo um panorama da mentali-

2] Ver os resumos das bulas de lohannes XXI em PotrhaST, A.: Regesta pontificum romanoru, t. II (pp. 1710-1718) R. Decker, Berlin 1875. Uma edição parcial do bulário encontra-se em Les registres de Jean XXI. Publiés par L. CADIER. in: Les registres de Grégoire X..., suivis du Registre de Jean XXI (BEFAR) Ed. A. Fontemoing: Paris 1898 e (índices:) 1960.

22 Ver 0 estudo de A. Fliche, cit. supra n. 2.

23 Bula editada na p. 234 de SÁ, Artur Moreira de: «Pedro Hispano e a crise de 1277...», art. cit. e no Cartularium Universitatis Pantisiensis, t. I (p. 541), Paris 1889. Quanto à existência de uma segunda bula ver supra n. 11. Sobre o papel residual de João XXI na condenação de 1277 ver: HisSETTE; Roland: Enquête sur les 219 articles condamnés à Paris le 7 mars 1277 (Philosophes médiévaux 22) Publications Universitaires, Louvain 1977; e BianCHI, Luca: Il lescoro e i filosofici. La condanna parigina del 1277 e l'eroluzione dell'aristotelismo scolastico (Quodlibet 6) Lubrina editore. Bergamo 1990.

24 Callebaut: André P. (OFM): «Jean Pecham, O.F.M. et l'augustinisme. Aperçus Historiques (12631285)», in Archivum Franciscanum Historicum 18 (1925) 441-472, cf. pp. 454-461.

25 GILSON, Étienne: «Les sources greco-arabes de l'augustinisme avicennisant», in Archives d'histoire doctrinale et littéraire du Moyen-Âge, 4 (1929/30) 5-149, cfr. pp. 105-107 (reed. do estudo: Vrin Reprise, Paris 1986).

26 Um exemplo recente poderá encontrar-se na oposição esquemática entre Siger de Brabante filósofo e Pedro Hispano não-filósofo, proposta no breve artigo de LiBERA, A. de: «Pierre d'Espagne, XIII.e siècle (Petrus Hispanus Portugalensis», in HuISMAN, Denis (dir.) Dictionnaire des philosophes, vol. II (K-Z), PUF, Paris 1984 (pp. 2064-2065). 
dade popular medieval sobre a ciência e os cientistas. Forma-se uma verdadeira lenda negra de um papa nigromante, que se julgava destinado a um longo pontificado, porque se vangloriava de deter os conhecimentos que lhe garantiam o prolongamento da vida, mas que seria fulminado por uma morte violenta e diabólica, castigo para a soberba e a imoderação de um homem que se dedicava a práticas obscuras, em busca da juventude eterna. ${ }^{27}$ Soberba inconsciente e herética, como conta o cronista Sifrido, para quem o papa estaria a ditar im certo livro herético e perverso quando o tecto, ferindo-o com tal gravidade que cinco dias depois morria dizendo constantemente «que acontecerá ao meu livro? quem terminará o meu livro?» ${ }^{28}$ Ignora-se que obra estaria a escrever, é mesmo improvável que escrevesse qualquer obra de ciência, mas a referência é elucidativa como exemplo da imagem negativa que se formou sobre a personalidade deste homem que atravessou o século XIII acumulando prestígio e rendas e que com saber e habilidade se manteve sempre no centro das instituições de poder do seu tempo. ${ }^{29}$

Estes breves elementos mostram-nos como a historiografia se tem apoioado em acumulações e associações, por vezes ousadas, para construir uma biografia para Pedro Hispano, afinal repleta de lacunas. A reapreciação dos documentos torna plausível a dispersão por vários personagens dos factos que até agora têm sido atribuídos ao Pedro Hispano que viria a ser papa João XXI. No entanto, apenas uma mais minuciosa análise dos documentos e a reconstituição dos mecanismos de repetição da historiografia petrínica poderiam conduzir a conclusões definitivas. ${ }^{30}$ É uma hipótese que o enaltecimento científico de João XXI, realizado pelos escritores eclesiásticos, seja uma compensação para a impressão muito negativa que a sua personalidade e acção pontifícia deixaram nos seus contemporâneos. Com os séculos, à medida que aqueles aspectos negativos vão sendo "explicados" vai emergindo um João XXI de crescente envergadura intelectual. ${ }^{31} \mathrm{~A}$ estratégia para o fazer foi precisamente acumular em um único Pedro todas as atribuições de obras dispersas por múltiplos manuscritos e edições. Ora, a análise das obras contribui com outros argumentos para a dissociação de autores.

27 Esta imagem negativa de João XXI foi sobretudo transmitida pelos cronistas e historiadores dominicanos, talvez agastados pelo envolvimento do papa na condenaçã̇o de 1277, a qual atingiu directamente 0 dominicano Tomás de Aquino e os seus seguidores.

28 Sifridi presbyteri de Balnhusin Historia universalis et Compendium historiarum, ed. O. Holder EGGER, Monumenta Germaniae Historica, t. XXV. Hannover 1880, p. 7.08.

29 A lenda negra de João XXI foi aproveitada com engenho literário no "thriller" de Roberto VACCA Dio e il compiuter que tem como personagem central o papa lógico, médico e alquimista (ed. Fabbri-Bompiani, Milano 1984; trad. port. Deils e o computador, ed. Afrontamento: Porto 1986).

30 Analisei estas repetições e citações acríticas na historiografia petrínica a propósito da atribuição do comentário à Phisiognomia que não the pertence mas que é sempre citado para mostrar os interesses científicos e naturalísticos do papa. cf. Meirinhos. J.F. «A atribuição a Petrus Yspanus das Sententie super libro de physonomia de Guillelmus Hispanus, no manuscrito Vaticano, Urb. lat. 1392», in Mediaeralia Textos e estudos 7-8 (1995) 329-359.

31. Para o comprovar vejam-se as opiniões dos seus contemporâneos Sifrido (cit. supra n. 28). MarTinHo Polono (cit. infra n. 41) e RiCobaldo de FerRaRa (cit. infra n. 45) e confrontem-se com as de Platina (Vitae pontificum.... Nuremberga 1481, p. 184a), GESNER (Bibliotheca Universalis..., Tiguri 1545, pp. 549-550), MACEDO (Lusitania Infulata et Purpurata... Parisiis 1663. pp. 36-58), PaLatio (Gesta Pontificum Romanorum..., t. III; Venetiis 1688, col. 73-78, onde explica a lenda negativa), EgGs (Vitae, res gestae ... Pontificum Romanorum, Coloniae 1718. pp. 478-481), MACHADO (Bibliotheca husitana, t. H. Lisboa 1747. pp. 559-562), etc. 


\section{AS OBRAS COMO PROBLEMA}

Durante muitos séculos o nome de Pedro Hispano andou apenas associado a obras de lógica como as Summulae logicales, ou de medicina como o Thesaurus pauperum. O panorama alterou-se radicalmente quando, por volta de 1920, Martin Grabmann realizou uma missão de estudo em bibliotecas espanholas e reparou nos manuscritos 1877 e 3314 da Biblioteca Nacional de Madrid, onde existem obras atribuídas a Pedro Hispano até aí esquecidas ou só referidas em uma ou outra publicação erudita. ${ }^{32}$ Com esta e outras descobertas que se lhes seguiram, começou a emergir um Pedro Hispano totalmente diferente, com uma obra extensa, diversificada e consistente, para o qual faltava apenas encontrar uma biografia onde se enquadrasse uma ampla evolução de pensamento para abarcar obras tão diversas. Mas, crescia simultaneamente o problema da autenticidade e da atribuição a um único Pedro Hispano de todas estas obras, tanto mais que de algumas das mais significativas apenas se conhece um ou dois apógrafos, e de outras cada manuscrito contém uma versão diferente. Como contributo para a clarificação da consistência histórica de Pedro Hispano, empreende-se neste parágrafo uma visão de conjunto sobre o corpus atribuído a Pedro Hispano, analisado-o nos seus grandes temas, formas literárias e difusão ou influência.

\section{a) Obras lógicas}

As mais espinhosas dificuldades surgem a propósito do Tractatus (título original, restituído por De Rijk na edição de 1972, da obra que se tornou famosa sob o nome Summulae logi-

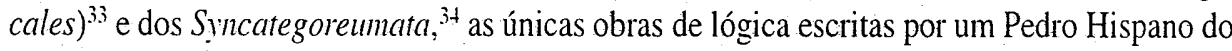
século XIII. Outros textos lógicos foram postos a circular sob o seu nome, para dele receberem prestígio e autoridade, mas não the pertencem. ${ }^{35}$ Pela natureza das doutrinas, das fontes e da sua primeira difusão, estes escritos, sobre os quais foram já aventadas as mais variadas e desencontradas hipóteses, deverão ter sido compostos na primeira parte do século XIII, fora do

32. Sobre as descoberta ver GRABMANn , Martin: «Die Lehre vom intellectus possibilis und intellectus agens im Liber de anima des Petrus. Hispanus des späteren Papstes Johanes XXI.», in Archives d'histoire doctrinale et littéraire du Moyen-Âge. 11 (1937-38) 167-208, onde cita outra bibliografia anterior. Um relato desta descoberta e do. seu impacto pode ler-se em Pontes. J.M. Cruz: A obra filosófica de Pedro Hispano Portugalense. Noros problemas textuais, Instituto de Estudos Filosóficos, Universidade de Coimbra, Coimbra 1972.

33 Cf. supra n. 4.

34 Cf. infra n. 52.

35. Entre estas obras apócrifas incluem-se as Fallaciae minores, que em alguns manuscritos substituíam o tratado VII (conhecido como Tracatus maiorum fallaciarum), como acontece no texto editado por I. BocHENSKI: Petri Hispani Summulae logicales, Ed. Marietti. Torino 1947, pp. 65-91. Um Tractatus exponibilium com que em muitos manuscritos e edições se completam os Tractatus foi-lhes anexado após 1350 e encontra-se por exemplo na edição de J.P. Mullally: The "Summulae logicales" of Peter of Spain, Notre Dame (Indiana) 1945, pp. 104-129. Os Sincategoremata que se seguem ao Tractatus nas edições de Colónia de 1489 e 1496, são de autor anónimo e nada têm com a obra de Pedro Hispano, editada por de Rijk em 1992. Também são apócrifos outros tratados incluídos na edição de Colónia de 1494 usada por Mullally, mas não reproduzidos: Tractatus obligatoriorum, Tractatus insolubilium, Tractatus consequentiarum. 
ambiente filosófico parisiense, embora o seu autor aí tivesse obtido a sua formação. ${ }^{36}$ Dois elementos fulcrais e definitivos para a identificação do autor do Tractatus são a determinação do local e contexto de composição e a sua datação, assunto sobre o qual tem havido as maiores oscilações. Se a obra foi composta após 1245 certamente que, por impossibilidade biográfica, não foi composta pelo Pedro que viria a ser papa João XXI e conhecer o local e o contexto escolar de composição também ajudaria a determinar se foi ou não escrita por esse Pedro. Estas questões, datação e local de composição, são dois dos mais fortes argumentos com que De Rijk reequacionou a identificação de Pedro Hispano com João XXI, ${ }^{37}$ mas o fundamento da sua hipótese de datação foi infirmado pela descoberta de Gauthier (cf. supra, n. 6) e quanto ao local de composição, baseado nos topónimos do exemplo de Exemplum (Tractatus V 3 , p. 58) é demasiado conjectural para se apresentar como indiscutível..$^{38}$

Pelos testemunhos e pela tradição manuscrita sabemos que o autor se chamava Pedro e era natural da península Ibérica. Se quanto a isto não há diferendos, quanto a outros aspectos há várias tradições desde o século XIII: uma que o toma como Mestre Pedro Julião Hispano, natural de Lisboa e futuro papa João XXI, outra que o toma como frade dominicano, natural ou sepulto em Estella, ou de outra região de Espanha. Desde muito cedo a identificação do autor tem sido polémica, e já em alguns manuscritos e catálogos do século XIII a obra tem sido atribuída a um Pedro Hispano dominicano, ${ }^{39}$ enquanto que na maioria dos testemunhos manuscritos da obra não é referida a sua pertença a qualquer ordem religiosa. Uma vez que o papa João XXI não foi dominicano, se se mostrar que o Pedro Hispano summulator foi dominicano, teríamos aí um forte elemento para a distinção dos dois autores. Mas, dado o estado do nosso conhecimento dos indícios documentais, a verificação dessa hipótese deve assentar simultaneamente na análise dos mais antigos testemunhos manuscritos, na identificação das famílias de difusão da obra, e na genealogia da historiografia pontifícia onde começa por ser

36 Uma das teses definitivamente esclarecidas é a da pretensa origem bizantina dos Tractatus, pretensamente escritos por Miguel Psello, que Pedro Hispano apenas teria traduzido. O que aconteceu foi precisamente o contrário, razão pela qual algumas interpretações da lógica medieval que seguiram esta "tese bizantinista" ficaram irremediavelmente afectadas, como sucede com a de PRANTL, Carl: Geschichte der logic im Abendland, vol. Il cap. XV. pp. 267-301 (1865, 2a ed. 1885); vol. III cap. XVII; sbd. pp. 33-74 (1867); vol. IV cap. XXII, pp. 211-219 (1870), reed. Buchhandlung Gustav Foch, Leipzig 1927. Uma história da "tese bizantinista" encontra-se em DE Risk, Peter of Spain Tractatus..., op. cit., pp. LXI-LXVII.

37 in Peter of Spain Tractatus.... op. cit. pp. LV-LXI.

38 O recurso a estes topónimos para determinar o local de composição da obra obrigou de Rijk a conjecturar uma permanência de Pedro Hispano na região de Léon (cf. «Introduction» pp. XXXVII, XLI, LV-LXI), facto hipotético totalmente ausente dos documentos e ignorado em todos os biógrafos. Esta permanência obrigaria: por sua vez: a que a obra tivesse sido escrita num período recuado da vida de Pedro Hispano sobre o qual não houvesse documentos, ou seja, antes de 1245 e antes dos estudos de medicina. Se estes topónimos possuem o significado que deles de Rijk extrai, isto é, que a obra foi escrita onde os termos do exemplo faziam sentido, poderíamos perfeitamente concluir que o autor da obra era natural de um desses locais referidos (León, Astorga, Zamora) e não português e lisbonense. Mas, a hipótese de de Rijk foi posteriormente tomada como certa: apesar das próprias cautelas do autor: «I must agree, there is no conclusive evidence for absolute certainty about neither the date of composition of the Tractatus nor its place of origin. What has been put forward here, is only meant as a hypotesis wich fits in as well as possible with the other data» (IDEM, ibidem, p. LXI).

39 Cf. os manuscritos e fontes citados por DE RIJk, Peter of Spain Tractatus..., «Introd.» pp. IX-XXIV. 
feita a atribuição do Tractatus ao papa João XXI, a qual, depois de incessantemente repetida, se transfere para a própria tradição manuscrita e impressa da obra, sem contudo chegar a eliminar a tradição que defende que o Pedro Hispano autor das súmulas era dominicano. ${ }^{40}$

Apenas como ponto de partida note-se que em nenhum dos mais antigos manuscritos do Tractatus se refere o seu autor como Petrus Juliani. Só em manuscritos tardios e em edições impressas onde o autor já é identificado com João XXI é que ele é assim chamado. Esta identificação do Tractatus com João XXI poderia ser explicada com base em associações sucessivas. Martinho Polaco, que foi penitencial e historiógrafo da cúria durante o papado de João XXI, refere-se-lhe como «in diversis scientiis famosus», para logo dizer que carecia de habilidade natural, pelo que a estupidez do seu carácter deformava a flor destas ciências e a dignidade pontifícia. ${ }^{+1}$ A partir desta amarga apreciação do papa não há, pois, motivos para duvidarmos da fama de João XXI em assuntos de ciência. Quais seriam estas ciências?+2 incluemse aí a lógica e a medicina? Martinho não o diz mas os historiadores sucessivos, seja por associação, seja dando corpo a uma tradição oral, virão a afirmá-lo. O franciscano Salimbene de Adamo na sua Cronica, escrita no final do século XIII, refere Mestre Petrus Hispanus, futuro João XXI, como «grande sofista, lógico e disputador e mesmo teólogo (magnus sophysta, loycus et disputator atque theologus)»..$^{43}$ Nesta passagem, cujo objectivo primeiro é elogiar João de Parma através da estima que por ele tinham outros homens pios e de ciência, não há uma referência clara às Summulae, embora habitualmente seja interpretada nesse sentido. ${ }^{\text {H }}$ Poderia estar aqui a origem da indentificação entre Pedro Hispano lógico e João XXI que viria a ser expressamente feita por Ricobaldo de Ferrara na História dos Pontífices romanos, escrita em 1297: «Johannes XXI, natione Hispanus (...) Cui nomen fuit Magister Petrus Hispanus qui Tractatus in logica composuit. $\aleph^{+5}$ Após esta identificação explícita, manter-se-ão as duas teses, sem que uma consiga verdadeiramente sobrepor-se à outra, razão pela qual Pedro Hispano summulator ora é apresentado como dominicano, ora como o futuro papa João XXI.

40 Angel D'Ors prepara um estudo que retoma a hipótese de Pedro Hispano ter sido um dominicano, portanto distinto do papa João XXI.

41 Martini Oppariensis Cronicon pontificum et imperatorum, ed. L. WEILAND, Monumenta Germaniae Historica, Scriptorum t. XXII, Hannoverae 1872, p. 443. Esta passagem também se pode ler no Liber Pontificalis, que como se sabe para o período 1130-1281 foi completado com a Crónica de Martinho, cf. Le Liber Pontificalis, ed. L. Duchesne, Broccard Ed., Paris 1955, p. 457.

42 Em um dos manuscritos da edição de Weiland lê-se "sententiis" em vez de "scientiis".

43 Cronica fratris Salimbene de Adam ordinis minorum, edd. O. Holder-EGGER: Monumenta Germaniae Historica, Scriptorum t. XXXII. Hannoverae et Lipsiae 1905-1913, p. 304.

44 Aliás, os qualificativos usados aplicar-se-iam mais directamente ao conteúdo dos Sincategoremas que ao Tractatus.

45 Riccobaldus Ferrariensis: Historia Pontificum Romanorum, ed. L.A. Muratori, Rerum italicarum scriptores t. IX, col. 181 (cit. DE RIJK. Peter of Spain Tractatus..., p. XIII). A identificação podia partir da fusão de duas informações: a de um Pedro Hispano autor do Tractatus, assimilado à fama sobre a ciência de João XXI, a qual Ricobaldo também refere na notícia da sua elevação ao cardinalato juntamente com «alium virum scientia aeque persimilem», in Historia Imperatorum, ed. L.A. MURATORI, Rerum italicarum scriptores t. IX, col. 140 (cit DE RIJK. idem, p. XIII n. 2). 
A questão da autoria das obras lógicas também não pode passar sem um confronto com as outras obras atribuídas a Pedro Hispano. Deixando de lado aquilo que serão coincidências de orientação próprias da época, deve notar-se que estas obras lógicas são muito diferentes no estilo, na terminologia, nas fontes, na estrutura e nas posições filosóficas, de obras como 0 Comentário sobre a alma, que das obras filosóficas atribuídas é considerada a mais antiga (porque dela estão ausentes os conhecimentos médicos). Um facto a merecer toda a atenção é que neste comentário, em que o autor cita outras obras suas, por sinal perdidas, não cita as obras de lógica, nem mesmo quando compara a lógica com a ciência da alma. ${ }^{46}$ Também nada permite aproximá-las das obras filosóficas e médicas.

O Tractatus é composto por 12 livros ou breves resumos dos grandes temas e problemas da lógica da primeira metade do século XIII usando uma fórmula que o tornou célebre nos tempos sucessivos. ${ }^{+7}$ Foi decisivo o seu contributo para fixar o estilo das summulae como uma forma literária de grande projecção académica durante a Idade Média. Nesta obra os assuntos são expostos com sobriedade didáctica, sem qualquer intenção heurística. O modo como está elaborado, com a cuidadosa omissão de todo o tipo de considerações ontológicas ou metafísicas, tornam-no passível de quase memorização, próprio para o ensino de principiantes e aberto a comentários de todas as escolas e correntes.

Desde cedo os comentadores identificaram as fontes e os limites da obra. Lê-se no início de um comentário renascentista anónimo: «Este é o primeiro tratado de mestre Pedro Hispano, no qual fixa resumidamente a matéria prolixamente tratada nos livros de lógica de Aristóteles, Porfírio e Boécio». ${ }^{+8}$ Num manuscrito do século XV diz-se «iste sunt sumule fratris P.H. que possunt dici flos ortus libri Aristotilis». ${ }^{+9} \mathrm{~A}$ obra é claramente posta por estes e outros comentadores sob a autoridade de Aristóteles e, portanto, vê-la como um resumo escolar é aqui um elogio. De facto, os tratados I-V e VII (introdução terminológica, predicáveis, categorias, silogismos, tópicos, falácias) resumem e codificam sob uma forma nova a logica vetus e as breves súmulas de lógica do século XII e início do XIII, que o Tractatus em boa parte viria a substituir. Os tratados VI e VIII-XII, constituem a chamada logica modernortum e ocupam-se das propriedades dos termos na proposição, tema que constitui a mais importante contribuição medieval para a história da lógica, onde ocupa lugar fulcral a teoria da suppositio, uma formulação da teoria da referência, que constitui como que o centro de todas as outras propriedades dos termos: relação, ampliação, apelação, restrição e distribuição. Quanto às suas fontes, esta parte terminista da obra ainda parece menos original porque coincide quase literalmente com umas Surnmulae antiquorum, também editadas por De Rijk. ${ }^{50}$ Se estas foram escritas antes

46 Cf. Com. in de anima q.p.3. pp. 139-140 (ed. M. Alonso Alonso, Pedro Hispano, Obras filosóficas t. II: Comentario al "De anima" de Aristoteles, CSIC, Madrid 1944).

47 O mais invocado exemplo desta fama são os versos de DANTE «e Pietro Ispano / Lo qual giù luce in dodici libelli», Commedia, Paradiso XII vv. 134-5.

48 ms. Praha, Universititní Knihovna. Osek 7.

49. Erfurt, Amplon. F. 263, f. 29v (cit. DE RuJ. Peter of Spain Tractatus..., op. cit., XI). Este manuscrito insere-se na tradição dos que consideram que 0 autor era dominicano, daí o chamar-lhe frater.

50 Ruj, L. M. DE: Logica modernorum, Vol. I (pp. 9-24), Van Gorcum, Assen 1962. Cf. De RuJ, Peter of Spain Tractatus..., op. cit., pp. XCIIl-XCIV. 
desta parte do Tractatus este nada tem de novo e a semelhança é tão flagrante e profunda que Gauthier põe a hipótese de as Summulae antiquorum serem uma primeira redacção da parte correspondente do Tractatus. ${ }^{51}$

Por sua vez os Syncategoreumata ocupam-se de um problema lógico complementar também relacionado com as propriedades dos termos, enquadrado logo nas primeiras linhas da obra: «Uma proposição é considerada verdadeira ou falsa consoante a coisa <envolvida> existe ou não. Ora a verdade ou falsidade de uma proposição é causada pelas expressões sincategoremáticas, como "apenas", "só", "senão", "excepto", etc. [...] Portanto, <os sincategoremas> significam coisas que são disposições de coisas que podem funcionar como sujeitos ou como predicados, uma vez que na proposição verdadeira ou falsa não existem senão o sujeito e o predicado e as suas disposições. $\nu^{52}$ Estamos pois no próprio coração da lógica filosófica, enquanto discussão da verdade na proposição como resultante da intersecção entre linguagem, pensamento e real. Os diversos problemas de semântica lógica aqui implicados são discutidos nos 10 tratados da obra ao longo dos quais se determinam as regras lógicas cuja validade formal é testada com a disputa de mais de 50 sofismas ou jogos lógicos (que nada têm a ver com falácias) de que são exemplo: «se nada existe alguma coisa existe», «ninguém está a ler em Paris, a não ser que seja um burro», «tu não podes negar que não és um burro», etc. A forma literária desta obra é um pouco diversa da do Tractatus (onde são também discutidos 15 sofismas), pois o maior recurso a questões acentua a dimensão dialéctica do discurso e da lógica. As fontes dos Sincategoremas são mais difíceis de identificar, não parecendo tratar-se de mera compilação de escritos alheios, apesar do evidente recurso a colecções de sofismas. Entre os autores citados encontram-se Aristóteles, Boécio, Donato, Prisciano e o próprio Pedro Hispano. Como se pode verificar através do "index auctoritatum" o autor dos Sincategoremas remete seis vezes para o seu próprio Tractatus (a que haveria a acrescentar outras citações indirectas), de onde se deve concluir que os Sincategoremas são mais recentes e que indubitavelmente as obras pertencem a um mesmo autor. Embora menos difundidos, de um ponto de vista filosófico e lógico, os Sincategoremas são mais inovadores e adquirem hoje mais importância que o Tractatus, devido à pregnância dos paradoxos na discussão contemporânea sobre os fundamentos da lógica, da semântica e da matemática.

O Tractatus e os Syncategoreumata têm uma evidente finalidade escolar e poderão mesmo ter tido origem em lições proferidas, talvez no sul de França ou no norte de Espanha por volta de 1225-35 como propôs De Rijk. Já segundo a opinião mais recente o Tractatus teria sido escrito «dans le midi de la France avant 1245; toute autre précision est illusoire». ${ }^{53}$

51 Gauthier, René-Antoine: «Préface»; in: Sancti Thomae de Aquino, Expositio libri peryermenias; op. cit. p. $51 *$.

52. Peter of Spain, Syncategoreumata I 1 (p. 38), ed. L.M. De RiJK, cit. supra n. 8.

53 Gauthier, R.-A., "Préface», in: Sancti Thomae de Aquino, Expositio libri peryermenias, ed. cit., p. 53*. O mesmo autor tinha já posto a hipótese de Pedro ter estudado medicina em Montpellier e ensinado filosofia natural em Toulouse por volta de 1240 (cfr. p. 241* em GauTHIER, R.-A.: «Introduction»; in Sancti Thomae de Aquino, Sententia libri de anima (pp:1*-294*). Opera Omnia, t. XLI,1. Comissio Leonina, Roma-Libr. Philos. J.Vrin. Paris 1984). A ligação a esta Universidade do sudeste da França apenas é conjecturada com base nas afinidades das obras 
O Tractatus disfrutou de uma extraordinária difusão após ter sido adoptado como livro de texto para o ensino da lógica pelos dominicanos e por universidades continentais como Paris, Toulouse, Bolonha, Salamanca, Colónia, Cracóvia, etc. ${ }^{54}$ Sobreviveram cerca de 300 manuscritos, uma grande parte dos quais contém comentários sem o texto mesmo, a que se juntam cerca de 200 edições impressas até ao século XVII ${ }^{55}$ difusão que atesta bem a popularidade da obra ${ }^{56}$. Este sucesso do Tractatus para o ensino da lógica a principiantes deve-se sem dúvida à neutralidade filosófica da exposição das matérias, facilmente apropriáveis pelas diferentes escolas e correntes que lhe insuflavam as doutrinas próprias. A obra foi suporte para todas as lógicas medievais, pois temos comentários tomistas e albertistas, escotistas e occamistas, realistas e nominalistas, dominicanos e franciscanos, teológicos e filosóficos, terministas e iconográficos, etc. Os Syncategoreumata tiveram uma difusão manuscrita e impressa muito mais reduzida, talvez porque esta parte da lógica sofreria uma evolução muito mais acentuada e criativa na baixa Idade Média, nomeadamente com a autonomização da literatura de sofismas e a proliferação das disputas "obrigacionais".

O Tractatus na Península Ibérica teve dois destinos. Quando a universidade portuguesa foi criada em 1289 não parece que o Tractatus tivesse sido adoptado como manual de lógica e teremos de avançar até ao século XV e XVI para encontrar referências à obra e, que se saiba, nenhum português a comentou ou traduziu (aliás em Portugal não existe qualquer manuscrito com obras atribuídas a Pedro Hispano). Em Espanha a sua influência foi enorme. Aí se conservam cerca de 20 manuscritos com a obra ou comentários, e foram realizadas outras tantas edições das Summulae em Alcalá, Salamanca, Sevilha e Barcelona, com comentários de Pedro

filosóficas com este meio intelectual, mas infelizmente nada existe que veridifique esta sedutora hipótese. A data de 1245 parece justificar-se pelo facto de após esta data um Petrus Yspanus, que seria a mesma pessoa: aparecer em Siena a ensinar medicina.

54 Sobre a fortuna universitária da obra: que nunca ultrapassou o Canal da Mancha, podem ver-se dois estudos recentes, um sobre a sua utilização em Bolonha no século XIV em MAIERÙ, Alfonso: «I commenti bolognesi ai Tractatus di Pietro Ispano», in: BUZZETTI, D. - FERRIANI, M. - TABARRONI, A. (ed.): L'insegnamento della logica a Bologna nel XIV secolo (Studi e memorie per la storia dell'Università di Bologna, n.s. 8) Istituto per la storia dell 'Università di Bologna. Bologna 1992. pp. 497-543; e outro estudo sobre o seu uso como livro de texto em Colónia, em BraAKHuIS, Henk A.G.: «School philosophy and philosophical schools. The Semantic-Ontological View in the Cologne Commentaries on Peter of Spain and the «Wegstreit»», in: A. Zimmermann (Hrg.): Die Kölner Universitat in Mittelalter: Geistige Wurzeln und Soziale Wirklichkeit (Miscellanea Mediaevalia 20) W. de Gruyter, Berlin-New York 1989, pp. 1-18.

55 Listas extensas mas incompletas dos comentários ao Tractatus podem encontrar-se em Ferreira. João: «As Súmulas Logicais de Pedro Hispano e os seus comentadores», in Colectânea de Estudos 3 (1952) 360-394 e em Mullally: J.: The Summulae logicales of Peter of Spain, ed. cit.: pp. 132-158.

56 Popularidade e difusão que teriam consequências profundas na transmissão do texto, que circulava em versões muito corrompidas e alteradas e onde vieram mesmo a ser introduzidos textos e obras de autores anónimos que eram atribuldas a Pedro Hispano certamente para as fazer usufruir da autoridade de que o seu nome gozava em lógica (cf. supra n. 35). Como se pode constatar pela edição crítica de de Rijk, a interpolação mais conhecida é a da definição de dialectica no início da obra (p.l). As interpolações e alterações são abundantes sobretudo nas edições impressas, que por isso são de muito pouca utilidade para o estudo da lógica petrínica: mas indispensáveis para a história da lógica em geral. 
de Espinosa, Augustino Sbarroya, Ferdinando de Enzinas, Francisco de Prato, Cristóvão de Medina, Tomás de Mercado, Roderico Cueto, entre outros anónimos. ${ }^{57}$

\section{b) Filosofia natural}

Seria de esperar que nas restantes obras atribuídas a Pedro Hispano se encontrassem referência aos escritos de lógica, que teriam começado a ser usados como livro de texto antes de 1250. Tal não acontece, nem mesmo no Comentário sobre a alma, que parece ser a mais antiga das obras filosóficas atribuídas a Pedro Hispano. ${ }^{58}$ Este silêncio é ainda mais estranho porquanto o autor cita aí várias obras suas hoje perdidas, como umas Questiones physice (cf. p. 113, 32-33) ou um In mathematicis $(461,6)$, para além de fazer referências a escritos seus sobre a definição e os acidentes (161, 8-10, tema que não se encontra nas obras de lógica), sobre a origem do intelecto $(530,32)$ e sobre a geração e o embrião $(738,27-30$, referência que poderia indicar o comentário ao De animalibus).

A obra onde se encontram estas referências foi editada por M. Alonso em 1944 com o título Comentario al de anima, mas é vulgarmente citada como Questiones libri de anima, título inadequado porque não corresponde exactamente ao conteúdo literário da obra, que não contém apenas questões. Três problemas preambulares sobre o objecto, a natureza e o método da ciência da alma, antecedem o comentário que está organizado em lições, cada uma composta por: a) explicação da intenção do autor, b) breve divisão e articulação do correspondente texto aristotélico, c) exposição das sentenças ou proposições defendidas por Aristóteles, d) e por fim as questões (cada questão, que pode ser subdividida em várias sub-questões, tem a seguintes partes: questio, rationes, ad oppositum, solutio, ad rationes). Corresponde pois ao estilo das Sententiae cum questionibus, como foi aliás assinalado por Gauthier. ${ }^{59} \mathrm{Da}$ obra conhecem-se hoje dois manuscritos que terminam em pontos diferentes mas em ambos os casos ex abrupto mais ou menos a meio do livro II da obra de Aristóteles (ficam incompletas as questões da lição relativa a 414b19-415a12), por isso não se sabe se o longo comentário também incluía o livro III. O método de leitura escolar e o desdobramento de mecanismos de abordagem do texto, as fontes aduzidas e os problemas discutidos indiciam, também segundo Gauthier, uma obra composta por volta de 1240 , talvez em Toulouse. ${ }^{60}$ Os autores árabes, sobretudo Avicena e em menor grau Averróis e Algazali, são os grandes mediadores da aproximação ao pensamento de Aristóteles, num quadro tocado pelo neo-platonismo do Liber de causis (curiosamente aqui atribuído ao commentator que por antonomásia na Idade Média designava Averróis), ${ }^{61}$ pela Fons vitae de Ibn Gebirol e por Maimónides (que devia conhecer apenas indirectamente). Entre as fontes latinas encontramos Boécio, Gundissalino, Alfredo Ânglico e o De spiritu et

57 Cf. supra n. 55.

58 Comentario al "De anima" de Aristoteles, ed. M. Alonso, Pedro Hispano Obras filosóficas, vol. II, CSIC, Madrid 1944.

59 Gauthier, R.-A.: «Introduction», in Sancti Thomae de Aquino, Sententia libri de anima, op. cit. p. 239*.

60 IDEM, ibidem, pp. 191* e 240*.

61 Cf. Comment., ed. cit., pp. 432 e 433. Mas esta forma de atribuição também se encontra nas Quaestiones super libro de crisi et super libro de diebus decretoriis Galeni, cf. ms. Madrid, BN, 1877, f. 250rb. 
anima (atribuído a Agostinho). Apesar destas fontes secundárias, invocadas apenas nas questões, a obra desenvolve-se ao ritmo do texto aristotélico e das discussões orais, de que as questões são decerto uma transcrição, procurando o autor manter-se próximo do pensamento de Aristóteles sem fazer grandes cedências de harmonização com as doutrinas base do cristianismo ou com outras interpretações. Ao abordar problemas controversos, como a natureza da matéria, a pluralidade das formas, as formas do conhecimento, ou outros, o autor tem o cuidado de enumerar as diversas soluções que na época se debatiam, propondo aos leitores/ouvintes que optem pela solução que pareça melhor, sem deixar de indicar a sua preferência. ${ }^{62}$

A Scientia libri de anima, outra obra que em um manuscrito se atribui a Pedro Hispano, ocupa-se do mesmo tema que a obra anterior, mas de uma forma muito diversa. ${ }^{63} \mathrm{O}$ pensamento de fundo e a terminologia usada são muito diferentes, de tal forma que, como afirmou Gilson, a obra «faz recordar a psicologia pia e retórica do século XII», com uma perspectivação da alma que evoca «a sua origem Cistercience». ${ }^{6+} \mathrm{A}$ terminologia usada e as doutrinas centrais, como o microcosmismo, as teorias da matéria e da substância, a inserção cósmica do intelecto, aproximam de facto a Scientia dos Chartrenses do século XII. A obra apresenta-nos uma perspectiva bem diversa da que encontramos no Comentário sobre a alma, pelo que se a Scientia libri de anima fosse atribuída a um mesmo autor configurava uma profunda e inexplicada inversão filosófica do pensamento do seu autor. Organizado em 13 tratados, o livro é um autêntico compêndio do estado e dos debates da ciência da alma em meados do século XIII. ${ }^{65}$ A estrutura da Scientia segue o De anima de Avicena, mas tratando com mais equilíbrio cada tema e acrescentado outros novos. O tratado I contém uma metafísica da alma: existência, essência, imortalidade, relação alma-corpo. O tratado II oferece uma súmula de todas as faculdades e actividades da alma, que nos tratados seguintes serão desenvolvidas (tem-se dito que nesta obra é difícil identificar do pensamento o autor, que se expressa de modo equívoco, mas neste tratado ele está todo sistematizado e resumido). Na parte central da obra dedicamse três tratados a cada divisão maior da alma (III-V: vegetativa; VI-VIII: sensitiva; IX-XI: intelectiva). Os dois últimos tratados são sobre a relação da alma com os órgãos corporais (tr. XII) e sobre a sinopse das teorias que Aristóteles expôs no Acerca da alma livro I (tr. XIII).

62 Cf. por exemplo Comment, ed. cit., p. 263, p. 656, etc.

63 Scientia libri de anima, ed. M. Alonso, Pedro Hispano Obras filosóficas I ( $2^{\text {a }}$ ed., Juan Flors Barcelona 1961). M. Alonso publicou em 1952 uma Expositio libri de anima existente no manuscrito Madrid B.N. 3314 como sendo de Pedro Hispano, apenas porque se encontrava junto à Scientia libri de anima. Apesar do esforço de argumentação de Alonso, que fez sobressair semelhanças entre as obras, esta atribuição é destituída de fundamento, como foi evidenciado pela historiografia filosófica. Como no manuscrito não se faz qualquer alusão ao seu nome também é errado atribuí-la a um Pseudo Pedro Hispano, como agora se faz; seria mais correcto designá-la como Anónimo de Madrid. As obras pertencem mesmo a manuscritos diferentes (um francếs, outro inglês) que o acaso da encadernação moderna juntou. Sobre a autenticidade da obra cf. PonTES, J.M.Cruz: A obra filosófica de Pedro Hispano.... op. cit., pp. 161-163.

64 GiLSON, Etienne: History of Christian Philosophy in the Middle Ages, Sheed \& Ward. London 1955, p. 320 (Gilson apresenta um resumo da Scientia nas pp. 319-322).

65 Sobre esta obra de Pedro Hispano remeto para MeIrinhos. J.F.: A fundamentação do conhecimento na «Scientia libri de anima» de Pedro Hispano Portugalense (diss. mestr., Porto 1989) e a bibliografia aí citada. 
A Scientia libri de anima é uma obra de notável engenho sistemático, onde se «ordena uma exposição compendiosa e perfeita sobre a natureza da alma e suas faculdades (...e são...) reunidas as verdades de todas as investigações em sentenças muito claras e breves.» ${ }^{66} \mathrm{Como}$ as teorias são acolhidas pela sua verdade, não é citado qualquer autor, apesar de ser possível identificar muitas transcrições literais. Trata-se pois de uma obra ambiciosa, inspirada no De anima de Avicena, escrita num estilo rebuscado, que dificulta a identificação do pensamento petrínico e que não contribuiu para a sua difusão. ${ }^{67}$ A composição da Scientia é normalmente situada após as obras médicas devido ao relevo de certas doutrinas médico-biológicas na argumentação. Mas, a presença da medicina não é assim tão extensa. Como é normal numa obra de psico-gnosiologia do século XIII as fontes são sensivelmente as mesmas do Comentário ao De anima, devendo acrescentar-se Dionísio pseudo-areopagita e um maior peso de Avicena; quanto à parte biológica são influentes os textos zoológicos e naturais de Aristóteles, obras de Avicena e um ou outro texto médico que também circulava nas escolas de Artes. Aparte esta proximidade superficial, algumas doutrinas particulares e centrais na antropologia e na gnosiologia do século XIII divergem profundamente entre o Comentário e a Scientia: natureza da alma, relação do corpo com a alma e suas faculdades, psicogénese do conhecimento, natureza do cognoscível, relação da vontade e do arbítrio com o a acção, metafísica da luz e conhecimento, contemplação e união do intelecto agente, interpretação dos pré-aristotélicos, organização e sistema das ciências naturais, etc. É difícil explicar tantas e tão profundas divergências na evolução do pensamento de um mesmo autor. Foi por isso proposto que a Scientia é uma obra tardia na produção petrínica, mas embora seja uma hipótese interessante, nenhum indício permite confirmar a proposta de Gauthier segundo a qual teria sido escrita «em Portugal, entre 1250 e $1260 »,{ }^{68}$ porque as actividades documentadas de Pedro Julião não admitem com facilidade esta hipótese e as orientações que perpassam a obra distinguem-na claramente das restantes atribuídas a Pedro Hispano. Por outro lado, torna-se difícil explicar um percurso que cronologicamente vai da lógica, aos comentários naturais, às obras médicas, terminando com este tratado avicenista e antropologicamente simbolista, para regressar às compilações e receituários médicos, sem que num mesmo período o autor se ocupe em simultâneao destas várias áreas. É este um problema que falta esclarecer, mas que poderia ser mais facilmente explicado admitindo que as duas obras sobre a Alma foram escritas por autores diferentes, com orientações e objectivos filosóficos diferentes. E se aceitarmos a subscrição que se lê no final da obra, a Scientia foi composta por um Petrus Hispanus Portugalensis (cf. supra n. 10), que deveria estar ligado ao ambiente monástico parisiense da primeira metade do século XIII. De qualquer modo, também o naturalismo das obras médicas atribuídas a Pedro Hispano contradiz frontalmente a psicologia simbolista deste tratado.

66 Scientia..., ed. cit., p. 5.

67 Sobre o problemático estilo argumentativo em uso na Scientia ver Ferreira, João: Presença do Augustinismo avicenizante na teoria dos intelectos de Pedro Hispano (Pars dissertationis), Editorial Franciscana, Braga 1959 [= Itinerarium 5 (1959) 29-68].

68 Gauthier, R.-A.: «Préface», in Sancti Thomae de Aquino, Sententia libri de anima, op. cit. p. 241*. 
O estudo da alma prolonga-se em Aristóteles nos Parva naturalia ${ }^{69}$ e o Liber de morte et vita et de causis longitudinis ac brevitatis vite ${ }^{70}$, aborda um desses temas, mas não é um comentário mas um tratado escrito no mesmo estilo literário e científico da Scientia, e com um alcance sistemático idêntico, o que atesta que são obra de um mesmo autor. Também a terminologia denota aquele ambiente chartrense referido a propósito da Scientia. O pequeno tratado alarga ao tema específico da vida e da morte e suas causas, as doutrinas sobre a alma e a relação alma/corpo, do ponto de vista da conservação da vida. Outra perspectivação destes problemas, mais somática e biológica mas onde não são esquecidos os problemas epistemológicos e gnosiológicos, encontra-se nos dois comentários sobre o De animalibus atribuídos a Pedro Hispano.

O De animalibus (nome dado a um conjunto de três obras biológicas de Aristóteles traduzido para latim em 19 livros por Miguel Escoto) ocupa um importante lugar na bibliografia petrínica, desde logo porque é a principal fonte zoobiológica dos escritos sobre a alma e das obras médicas, mas sobretudo porque lhe são atribuídos dois comentários diferentes sobre a obra.$^{71}$ Ambas as versões são comentários por questões, embora as respectivas estruturas e organização divirjam bastante e haja mais diversidade de conteúdo que semelhanças. ${ }^{72} \mathrm{~A}$ recensão de Florença ${ }^{73}$ parece ser posterior à de Madrid, ${ }^{74}$ que Alberto Magno seguramente conhecia e utilizou por volta de 1258 nas suas Questões sobre o de animalibus. ${ }^{75} \mathrm{O}$ texto do manuscrito de Madrid não é propriamente um comentário mas mais uma colecção de questões (uma grande parte das quais são quesitos de tipo salernitano), e foi uma mão posterior à do copista que inseriu os lemas do texto de Aristóteles e numerou a sucessão dos livros, cujo conteúdo por vezes não corresponde às questões apresentadas. $\mathrm{O}$ texto de Madrid teve alguma

69 Nas Glose in Isagoge ad artem parram Galeni Pedro Hispano remete em dado passo para o seu comentário ao De sensu et sensato, obra hoje perdida, cf. manuscrito Madrid. B.N., 1877, f. 32va-b.

70 Cf. Tractatus bonus de longitudine et brevitate vite, ed. M. ALONso, Pedro Hispano Obras filosóficas t. III (pp. 413-490) CSIC, Madrid 1952.

71 Sobre estes comentários ver a recente tese de AsúA, Miguel J.C. de: The Organization of Discourse on Animals in the Thirteenth Century: Peter of Spain, Albert the Great, and the Commentaries on "De animalibus", Phi. Diss. University of Notre Dame (Indiana) 1991. Sobre os dois comentários, sua descoberta, respectivos manuscritos e conteúdo, ver Pontes. J.M. da Cruz: A obra filosófica de Pedro Hispano..., op. cit., pp. 53-102.

72 Cf. Asúa, M.J.C. de: The Organization of Discourse on Animals..., op. cit. pp. 47-86. De Asúa atribui a Pedro Hispano somente o comentário de Madrid, que teria sido composto durante o período de ensino da medicina em Siena (1245-1250), o comentário de Florença seria no máximo obra de um discípulo. Cruz Pontes começou por atribuir a Pedro Hispano apenas o comentário de Florença, por exemplo na sua tese Pedro Hispano Portugalense e as controvérsias doutrinais do século XIII. A origem da alma. Univ. de Coimbra 1964, com argumentação que resumiu em «L'interêt philosophique de deux commentaires inédits sur le "De animalibus" et le problème de leur attribution à Petrus Hispanus Portugalensis», in La filosofia della natura nel medioero-Atti del terzo Congresso Inteinazionale di. Filosofia Medioerale (pp. 493-501) Milano 1966. Mas, sob a influência de uma tese de M. Golsdtein-Préaud viria a aceitar a autoria petrínica de ambos os comentários em IDEM: A obra fillosófica de Pedro Hispano..., pp. cit.

73 Firenze, Biblioteca Nazionale Centrale, F.c.s., G.4.853, ff. 79-191.

74 Madrid, Biblioteca Nacional, 1877 ff. 256r-299r.

75 Albertus Magnus, Quaestiones super de animalibus, quas reportauit frater Conradus de Austria, ed. E. FilTHAut in Alberti Magni opera omnia, t. XII (pp. 77-309) Aschendorf 1955. 
difusão adicional através de' uma colectânea de 127 questões abreviadas dele extraídas, conhecida como Problemata, de que se conhecem 11 manuscritos, alguns dos quais expressamente atribuídos a Pedro Hispano, o que pode ser tido como prova adicional da autenticidade do apógrafo de Madrid. Os Problemas tiveram um certo sucesso e foram mesmo utilizados e citados por enciclopedistas dos séculos XV e XVI. ${ }^{76}$

O comentário ao De animalibus do manuscrito madrileno é totalmente diferente no conteúdo e no estilo literário do comentário do manuscrito florentino. Neste caso também estamos perante uma obra do tipo Sententice cum questionibus: cada lição compõe-se de lema, divisão do texto, determinação da intenção e sentenças de Aristóteles e questões ao estilo escolástico. É uma obra que devemos aproximar do Comentário sobre a alma, porque seguramente pertencem ao mesmo autor. O naturalismo filosófico que as atravessa e o estilo de lição mostram que se trata de obras compostas no âmbito de uma faculdade de Artes entre 1245 e 1260, o que torna quase impossível uma aproximação por uma lado com a Scientia libri de anima e por outro com as obras médicas atribuídas a Pedro Hispano. Identificar o seu autor é um problema ainda maior que o das restantes obras.

Entre as obras de filosofia natural atribuídas a Pedro Hispano deve ainda ser referido o De rebus principalibus naturarum, de que apenas se conhece o início. ${ }^{77}$ A sua temática e terminologia está muito próxima dos métodos simbolistas da astrologia e da alquimia, obras que alguns manuscritos e uma persistente tradição têm atribuído a Pedro Hispano e que hoje são consideradas pseudónimas, porque as suas doutrinas parecem ser incompatíveis com as obras de filosofia natural. ${ }^{78}$ Mas, deve notar-se que estão muito próximas de opiniões que se encontram nas obras médicas e entroncam numa preocupação que a tradição atribui a João XXI: os segredos da conservatio e da prolongatio vitae. A sua autenticidade e a de outros textos do mesmo tipo deveria ser discutida no quadro das obras médicas e não no da obra filosófica (que como me inclino a pensar pertence a outros Pedros). Como comprovei em outro estudo, não pertence a qualquer Pedro Hispano o comentário à Fisiognomia do pseudo-Aristóteles, que lhe é atribuído em um manuscrito por erro do copista. ${ }^{79}$

\section{c) Mística e apologética}

A Pedro Hispano é também atribuída uma Expositio librorum beati Dyonisii, ${ }^{80}$ atribuição que tem sido profundamente debatida, com a crítica mais recente a inclinar-se para a sua auten-

76 Uma edição dos Problemata encontra-se em Asúa. The Organization..., op. cit. pp. 359-403. Ver também, Lawn. Brian: The Salernitan Questions. An Introduction to the History of Medieral and Renaissance Problem Literature, Clarendon Press, Oxford 1963, pp. 76-78 (trad. ital. revista pelo autor: I quesiti salernitani, Di Mauro, Napoli 1969); e o estudo de NAGEL. Silvia: «Antropologia e medicina nei Problemata di Pietro Ispano», Medioero 17 (1991) 221-248.

77 Ed. por Alonso, M., Pedro Hispano Obras filosóficas t. III, pp. 493-502.

78 PonTES, A obra filosófica de Pedro Hispano..., op. cit., pp. 175-186.

79 Cf. MeIrINhos, J.F.: «A atribuição a Petrus Yspanus das Sententie super libro de physonomia ...», art. cit.

80 Ed. Alonso, M., Expositio librorum beati Dyonisii, IAC, Lisboa 1957. Esta Expositio abrange todas as obras de Dionísio pseudo-areopagita conhecidas no Ocidente a ainda as cartas 1-6. 
ticidade. ${ }^{81} \mathrm{~A}$ atribuição a Pedro consta apenas em um dos três manuscritos conhecidos (um dos quais é parcial). Recentemente localisei outro manuscrito completo, o qual poderá trazer novos elementos para a questão, entre os quais a possibilidade de a obra ser associada a um Pedro Hispano dominicano. A Exposito petrínica é uma simples explicação corrida dos textos de Dionísio baseada na Extractio de Tomás Galo, que já é uma interpretação literal dessas obras, escrita em Vercelli por volta de 1238. Trata-se de uma glosa e não de um comentário, cujo conteúdo é de pouca importância teológica, mas é de grande utilidade para esboçar uma evolução do pensamento de Pedro Hispano, ou para distinguir entre vários Pedros Hispanos. Teria sido escrita antes da Scientia, obra onde ocupam lugar de destaque as doutrinas dionisianas de hierarquia (ordo) e da iluminação (metafísica da luz), enquanto que no Comentário co De anima não encontramos traços dessas teorias. Esta exposição poderia constituir o elemento de ligação entre os interesses naturalísticos do Comentário sobre a alma e as preferências especulativas e simbolísticas da Scientia, mas dificultaria a explicação do posterior regresso aos problemas, temas e terminologia próprios dos escritos naturais e médicos. A datação destas paráfrases é balizada por uma referência ao «imperatore Frederico» em cuja posse se diz estar o De anima de Dionísio (p. 317), o que pressupõe que ainda estaria vivo, ora como o imperador morreu em 1250 e a Extractio de Tomás Galo foi composta por volta de 1238, a glosa foi escrita entre estas duas datas.

Lugar à parte ocupam uns sermões dominicais, inéditos e nunca estudados, que se conservam em 4 manuscritos (aliás diferentes entre si). São 155 homilias de tempore sobre temas litúrgicos dominicais, cuja insersão na vida e nas obras de Pedro Hispano é muito difícil de explicar (talvez por essa razão nunca houve coragem para os estudar). Os sermões são atribuídos a um «fratris petri yspani de ordine predicatorum», ${ }^{82}$ pelo que do seu estudo poderão advir novos elementos para a identificação de um Pedro Hispano dominicano, a quem, como vimos, em muitos manuscritos e catálogos medievais também é atribuído o Tractatus de lógica, e que poderia ser também o autor dos comentários a Dionísio.

\section{d) Medicina}

O mais importante testemunho da obra médica de Pedro Hispano é o manuscrito 1877 da Biblioteca Nacional de Madrid, em cujos 290 grandes fólios, escritos em letra pequena, se encontram 3.000 questões relativas a 10 comentários médicos e ao In de animalibus, referido atrás. É quase impossível determinar uma cronologia para as obras médicas, que em títulos e volume constitui a parte mais extensa das obras atribuídas a Pedro Hispano: Parece ser a parte mais tardia desses escritos, com os comentários a serem situados no período de Siena (1245?1250) e a composição dos receituários a ser prolongada mesmo até ao papado. Estas obras

81 Ver BaRboSA: João Morais: "O legado do "Corpus Areopagiticum" no Ocidente. A "Expositio in librum de mystica theologia" de Pedro Hispano», in Cultura. História e Filosofia 1 (1982) 25-44.

82 Cf. ms. Firenze, BNC. F.c.s., E.1.159, f.1. Uma lista do tempo, rubrica e incipit de cada sermão encontrase em SCHNEYER, Johannes Baptist: Repertorium der Lateinischen Sermones des Mittelalters, für die Zeit ron 1150 1350. Band 4 : Autoren L-P (BGPTM 43,4) Aschendorf V., Münster 1972. pp. 652-663. 
podem ser classificadas pelo estilo literário e pela sua finalidade: por um lado os comentários dirigidos a um público académico e por outro os especializados e receituários dirigidos sobretudo à auto-utilização pelos que têm menos posses.

Os comentários médicos tiveram alguma difusão e influência até ao início do século XVI, quando foram editados os três comentários a Isaac Israelita. ${ }^{83}$ Eles abarcam uma boa parte do corpus médico greco-árabe traduzido no século XII que circulava sob o nome colectivo de Articela, na qual assentava o ensino universitário da medicina no século XIII. ${ }^{84}$ Para além dos comentários a Isaac, já referidos, conhecemos em duas dezenas de manuscritos os seguintes textos de Pedro Hispano: as Glose super Tegni seu in artem parvam Galeni, as Notule super Johannicium Ysagoge ad Tegni <Galeni>, as Quaestiones super libro de crisi et super libro de diebus decretoriis Galeni, umas Notule super regimen acutorum Hippocratis, os Problemata supra prognostica Hippocratis, as Questiones super libris aphorismorum Hippocratis, as Questiones super de pulsibus Filareti, e as Quaestiones super Viaticum Constantini.$^{85}$ Estes comentários, onde é usada uma vasta gama de fontes, só poderiam ter sido compostos no período senense entre $1245-50$ e, como tem sido realçado, têm uma forte ligação com o meio médico salernitano, sendo mesmo vistos sob a influência da obra de Bartolomeu salernitano. ${ }^{86} \mathrm{Se}$ excluirmos que não estamos perante atribuições erradas, a existência de versões múltiplas de alguns dos comentários indicia um trabalho de revisão ou o resultado de cursos proferidos em universidades diferentes ou em anos diferentes. Todos estes comentários e glosas são sob a forma de questões, introduzidas por uma breve dilucidação do texto comentado, exactamente como o comentário ao De animalibus do manuscrito madrileno, que pode ser aproximado destas obras médicas.

Existe tambẻm uniformidade formal entre as compilações de receitas extraídas de outras obras, ou tomadas da tradição popular ou da autoria de Pedro Hispano. ${ }^{87}$ O Thesaurus paiupe-

83 ISAAC, Omnia opera Ysaaci, vol. I, Lugduni 1515, ff. 11-203. De Pedro Hispano, identificado no volume com João XXI, editam-se o Commentarium super librum dietarum universalium Isaaci (ff. 11-103), o Commentarium super librum dietarum particularium Isaaci (ff. 103-156) e o Commentarium super librum urinarum Isaaci (ff. 106rb-203vb). Estas versões são muito diferentes das dos manuscritos, onde, por sua vez, se conservam pelo menos duas versões diferentes de alguns desses comentários.

84 PESENTI, T.: «Arti e medicina: la formazione del curriculum medico», in Lioghi e metodi di insegnamento nell'Italia medioevale (secoli XII-XIV). (pp. 155-77) Congedo Editore 1989, onde também é referido o papel de Pedro Hispano na difusão mèdieval da Articella.

85 A edição das duas versões da parte sobre o mal de amor nesta última obra encontra-se em WACK, Mary Frances: Lovesickness in the Middle Ages. The Viaticum and its Commentaries, Univ. of Pennsilv. Press, Philadelphia 1990, pp. 210-251.

86 Ver a propósito o estudo da obra médica de Pedro Hispano, baseado sobretudo no manuscrito 1877 da Biblioteca Nacional de Madrid, em Morpurgo, Piero: L'idea di natura nell'Italia Normannosiera, introd. di A. MurRar, Ed. CLUEB, Bologna 1993, pp. 109-146.

87 Integram este grupo: o Liber de conservanda sanitate, que inclui a Summa de conservanda sanitate e os opúsculos De his que conferunt et nocent e Qui rult custodire sanitatem stomachi (ed. PEREIRA: Obras..., cit. na nota seguinte, pp. 427-500), o De Regimine Sanitatis per omnes menses (ed. Pereira: Obras.... pp. 414-419), as Dietae super cyrurgia (ed. K. SudHOFF in Beitrage zur Gesch. der Chirurgie 2, 1918: 395-398) e ainda o Tractatus de febribus com que geralmente termina o Thesaurus pauperum (cf. nota seguinte). A estas obras deveriam acrescentar-se um Tractatus de anathomia e um De phlebotomia, conhecidos em apenas um manuscrito cada. 
rum, uma compilação com finalidade prática e dirigida às gentes de menores recursos, oferece milhares de receitas sobre todas as doenças, desde os cabelos até às unhas dos pés, e nele se combinam sem distinção a dietética, a farmacopeia e a magia. ${ }^{88} \mathrm{~A}$ obra disfrutou de grande popularidade, atestada pelas traduções medievais para italiano, português, castelhano, catalão, francês, inglês, alemão, hebraico e, um pouco mais tarde, para russo. Testemunho desta extraordinária difusão são os cerca de 100 manuscritos e as muitas dezenas de edições conhecidas. Sendo uma compilação, prestava-se a todo o tipo de acrescentos e supressões, pelo que a sua história literária é extremamente complexa. Também os receituários de oftalmologia tiveram grande difusão ${ }^{89}$ por exemplo, Miguel Ângelo copiou algumas receitas para tratar as afecções dos olhos de que padeceu quando pintava 0 tecto da capela Sistina. ${ }^{90}$

Nas obras médicas é evidente a predilecção de Pedro Hispano pela higiene e dietética, consideradas a melhor via para a conservação do regime do corpo, evitando assim a necessidade de recorrer à medicina curativa, o outro ramo desta arte. Os receituários abrangem quer a conservação quer a cura do corpo, advertindo sempre que a conservação é mais importante que a cura. Os pares de contrários quente-húmido/frio-seco permitem compreender o funcionamento e a acção dos elementos no corpo vivo. Os princípios cósmicos de atracção-do-semelhante e repulsão-do-contrário explicam a acção dos elementos, das substâncias, das drogas e dos simples no restabelecimento do equilíbrio do corpo e a opção por certas panaceias de tipo mágico e pelo recurso a concepções astrológicas.

Para lá do seu interesse científico, as obras de medicina tềm também clara importância filosófica sobretudo quando são discutidos tópicos relacionados com os métodos das ciências, os graus de certeza do saber médico, as diferenças entre argumentos filosóficos e argumentos médicos, a natureza e fins do homem, a teoria das causas e a inter-acção dos elementos, a natureza e a origem da alma, os modos do conhecimento, a relação alma-corpo, o papel das paixões na explicação do agir humano, etc. ${ }^{11}$ As obras médicas são também uma inesgotável fonte para o estudo das ideologias da ciência médica medieval: superioridade do homem e inferioridade da mulher, relações entre sexualidade e saúde, magia e cura, etc. ${ }^{92}$

88 Estudos e edição crítica por Pereira, Maria Helena da Rocha: Obras médicas de Pedro Hispano (Acta Universitatis Conimbrigensis), Coimbra 1973, pp. 1-408, o Tractatus de febribus encontra-se nas pp. 303-323.

89 Trata-se das obras Aqua mirabilis ad risum consenandum ou Secretum de oculis e do De egritudinibus oculorum et curis. Estas obras, transmitidas pelos manuscritos geralmente em conjunto, foram reunidas e editadas sob o título comum mas inadequado De oculo por BERGER, Albrecht Maria: Die ophtalmologie (liber de oculo) des Petrus Hispanus (Petrus von Lissabon, später Papst Johannes XXI.). Text und übersetzung. Verlag von J.F.Lehmann, München 1899, respectivamente nas pp. 1-43 e 44-82.

90 Manuscrito autógrafo, Vaticano, BAV, Vat. lat. 3211.

91 Ver um estudo indicativo em SCHIPPERGES, Heinrich: «Grundzüge einer scolastischen Antropologie bei Petrus Hispanus», in Aufsätze zur Portugiesischen Kulturgeschichte, Portuguiesische Forschungen der Görresgesellschaft Münster, I,7 (1967) 1-51 e a anterior bibliografia do autor aí citada. Na sua leitura deve ser tida em conta a questão entretanto revista da atribuição de algumas obras a Pedro Hispano.

92 Um exemplo pode ler-se no capítulo dedicado à teoria petrínica do mal de amor em WACK. Mary F.: Lovesickness in the Middle Ages..., ed. cit. 
Quanto à questão da identificação do Pedro Hispano ao qual estas obras são atribuídas há alguns escolhos que convém reanalisar. Uma vez que são transmitidos por famílias de manuscritos completamente diferentes, tratar-se-ia antes de tudo de saber se o autor dos comentários é o mesmo dos receituários. Depois falta saber se o autor ou autores, ou apenas um deles coincide(m) com o Petrus Juliani que foi papa. Ao mesmo tempo terão de averiguar-se as relações destas obras médicas com as obras lógicas, as filosóficas e as teológicas referidas atrás. Os respectivos conteúdos mostram diversidade a mais para terem sido compostas por um mesmo autor no curto período de 15 a 20 anos (1230/5-1250).

Hoje sabemos que pelo menos alguns textos foram atribuídos a Petrus Hispanus por erro dos copistas ou dos editores e que outros são de pseudoepígrafos que procuravam o prestígio de que o nome Petrus Hispanus disfrutava, enquanto outros poderão até ter sido aproximados do seu nome numa estratégia difamatória do papa João XXI. Alguns escritos podem pertencer a diferentes autores com o mesmo nome, mas a tradição historiográfica teve sempre tendência a unificá-los e a repetir essas identificações e testemunhos sem a análise as suas fontes. A chave para a interpretação do "puzzle" Pedro Hispano tem sido a convergência para a tese do personagem único, sem se prestar a devida atenção às diferenças e por vezes contradições entre as obras que lhe são atribuídas. O tratamento da matéria documental, que tem uma dimensão apreciável, também tem sido orientado no sentido da identidade de um só Petrus Hispanus, por sua vez identificado com Iohannes XXI. Como vimos, para preencher as lacunas destas assimilações têm sido sugeridas hipóteses de difícil comprovação.

Com este estudo pretendeu-se reabrir a análise quer das lacunas biográficas quer das contradições e divergências entre as obras que são atribuídas a Pedro Hispano. Tendo em conta os elementos aduzidos, parece plausível sugerir que lhe têm sido atribuídos factos e obras de pelo menos três Pedros Hispanos diferentes:

\section{Petrus Hispanus, O.P.:}

Autor do Tractatus e dos Syncategoreumata. Poderia ser também o autor dos Sermones e mesmo da Expositio das obras de Dionísio, que por vezes também é atribuída a um Petrus dominicano. De qualquer forma, tudo aponta para um autor natural do centro norte de Espanha, distinto do autor das obras médicas e filosóficas e do papa João XXI.

\section{Petrus Hispanus Portugalensis:}

Autor da Scientia libri de anima e do Liber de morte et vita..., natural de Portugal e com alguma relação com meios chartrenses, teria escrito estas obras na primeira metade do séc. XIII (antes de 1240?), poderia ser também o autor da Expositio das obras de Dionísio. Ficaria por determinar a quem pertence o Comentário ao De animalibus do manuscrito de Florença e o Comentário ao De anima editado por Alonso, obras que pertenceriam a outro autor. 


\section{Petrus Hispanus medicus (= a Petrus Juliani?):}

Autor dos comentários médicos e do Comentário ao De animalibus do manuscrito de Madrid. Poderá ser ou não o mesmo autor dos receituários médicos. A identificação deste autor permitiria ainda determinar se este Petrus Hispanus é o Petrus Juliani lisbonense que veio a ser o papa João XXI.

A distinção entre estes autores, admitida pelos documentos e pelas obras, permitiria simplificar e resolver o "puzzle" Petrus Hispanus.

José Francisco Meirinhos

Rua de Paredes, 25

P-4100 PORTO (PORTUGAL) 